\title{
PENGARUH KOMUNIKASI INTERPERSONAL GURU DALAM MENGIKATKAN RASA PERCAYA DIRI ANAK USIA DINI
}

\author{
Gunawan Saleh \\ Program Studi Ilmu komunikasi Universitas Abdurrab, Indonesia \\ Email : gunawan.saleh@univrab.ac.id
}

\begin{abstract}
Abstrak
Penelitian ini bertujuan untuk mengetahui apakah terdapat pengaruh komunikasi interpersonal guru dalam meningkatkan rasa percaya diri anak usia dini di Raudatul Athfal Asiah Kota Pekanbaru. Penelitian ini dilakukan di Raudatul athfal Asiah Kota Pekanbaru. Penelitian ini menguji ada atau tidaknya pengaruh indicator dari faktor X (Komunikasi Interpersonal) yaitu percaya (trust), sikap suportif (suportif attitude), dan sikap terbuka (open mindedness) dengan indicator dari sikap percaya diri yaitu kemampuan pribadi, keberhasilan, keinginan, dan tekat yang kuat. Hasil penelitian membuktikan hipotesisal ternatif dapat diterima dengan nilai $t$ hitung $(10,284)>t$ tabel $(1,480)$ dan tingkat signifikan $(0,000)<0,05$. Maka $\mathrm{H}_{0}$ ditolak dan $\mathrm{H}_{\mathrm{a}}$ diterima, artinya komunikasi interpersonal guru memberikan pengaruh yang signifikan dalam meningkatkan rasa percaya diri anak usia dini.
\end{abstract}

Kata Kunci : Komunikasi Interpersonal, Guru, Percaya Diri Anak

\begin{abstract}
This study aims to determine whether there is influence interpersonal communication of teachers in improving confidence early childhood in raudatul Athfal Asiya Pekanbaru City. This research was conducted in RA raudatul Asiya Pekanbaru City. This study examined whether or not the influence indicator of factor $X$ (Interpersonal Communication) that believe (trust), attitudes supportive (supportive attitude), and openness (open-mindedness) with indicator of the attitude of confidence that personal ability, success, desire, and strong embroidery. Ternatif hipotesisal research proves acceptable to the value of the $t(10.284)>t$ table (1.480) and a significant level $(0.000)<0.05$. Then HO is rejected and Ha accepted, meaning that the teacher interpersonal communication have a significant effect in improving confidence early childhood where the students Raudatu l Athfal Asiya Pekanbaru. and openness (open-mindedness) with indicator of the attitude of confidence that personal ability, success, desire, and determination strong. Ternatif hipotesisal research proves acceptable to the value of the $t$ (10.284) $>t$ table (1.480) and a significant level $(0.000)<0.05$. Then $\mathrm{HO}$ is rejected and Ha accepted, meaning that the teacher interpersonal communication have a significant effect in improving confidence early childhood.
\end{abstract}

Keywords : Interpersonal Communication, Master, Confident Kids 


\section{PENDAHULUAN}

Membangun rasa percaya diri anak sejak dini, sangat penting bagi orang tua dan guru, dengan harapan agar anak sejak dini memiliki kepercayaan diri dan karakter yang baik. Anak usia dini menduduki posisi penting dan menjadi acuan utama dalam pemilihan pendekatan, model, dan metode pembelajaran. Anak usia dini adalah anak yang baru dilahirkan sampai usia 6 tahun. Usia 4-6 tahun merupakan masa peka yang penting bagi anak untuk mendapatkan pendidikan. Pengalaman anak yang diperoleh dari lingkungan, termasuk stimulasi yang diberikan oleh orang dewasa, akan mempengaruhi kehidapan anak dimasa yang akan datang. Oleh karena itu diperlukan upaya yang mampu memfasilitasi anak dalam masa tumbuh kembangnya, berupa kegiatan pendidikan dan pembelajaran sesuai dengan usia, kebutuhan dan minat anak.

Anak usia dini adalah individu yang sedang mengalami proses pertumbuhan dan perkembangan yang sangat pesat, bahkan dikatakan sebagi lompatan perkembangan. Anak usia dini memiliki rentang usia yang sangat berharga dibanding usia-usia selanjutnya karena perkembangan kecerdasannya sangat luar biasa. Usia tersebut merupakan fase kehidupan yang unik, dan berada pada proses perubahan berupa pertumbuhan, perkembangan, pematangan dan penyempurnaan, baik pada aspek jasmani maupun rohaninya yang berlangsung seumur hidup, bertahap, dan berkesinambungan. (Mulyasa, 2012 :16)

Dalam implementasinya, Pendidikan Anak Usia Dini yang disingkat PAUD, berfungsi menumbuh kembangkan seluruh potensi anak secara optimal, agar tebentuk perilaku dan kemampuan dasar yang selaras, serasi, dan seimbang dengan tahap perkembangannya.Mengingat pentingnya PAUD tersebut, pemerintah telah mengeluarkan, berbagai kebijakan untuk mengatur implementasinya agar dapat dilakukan secara optimal. Guru mengambil peran penting yang tidak terlepas dari kegiatan belajar mengajar yang terjadi di Raudatul Athfal. Sebagai tenaga pengajar guru Raudatul Athfal tentunya dituntut untuk dapat memberikan pendidikan dasar bagi anak usia dini agar menjadi anak yang bermoral, memiliki aqidah yang kuat serta memiliki karakter dan memiliki rasa percaya diri. Cara seorang guru berkomunikasi tentunya menentukan bagaimana seorang guru dapat menanam aqidah yang kuat serta memiliki karakter dan memiliki rasa percaya diri.

Melihat fenomena di atas, menarik untuk dikaji lebih jauh apakah komunikasi interpersonal guru yang terjadi pada proses belajar mengajar di Raudatul Athfal berpengaruh terhadap murid Raudatul Athfal dan menjadi dasar seorang anak merasa siap menghadapi lingkungannya dan percaya diri untuk menempuh pendidikan lanjutan yaitu sekolah dasar.

\section{KERANGKA TEORI}

\section{KomunikasI Interpersonal}

Komunikasi antarpribadi (interpersonal cmmunication) adalah komunikasi antar orang-orang secara tatap muka, yang memungkinkan setiap pesertanya menangkap reaksi orang lain secara langsung, baik secara verbal ataupun nonverbal. (Mulyana, 2011 : 8) Komunikasi antarpersonal (interpersonal communication) adalah komunikasi antara seseorang komunikator dengan seorang komunikan. Komunikasi jenis ini diang- 
gap paling efektif dalam hal upaya mengubah sikap, pendapat, atau perilaku seseorang, karena sifatnya dialogis, berupa percakapan. (Effendi, 2008: 8)

Komunikasi interpersonal adalah proses pertukaran informasi di antara seseorang dengan paling kurang seorang lainnya atau biasanya di antara dua orang yang dapat langsung diketahui balikannya. Dengan bertambahnya orang yang terlibat dalam komunikasi, menjadi bertambahlah persepsi orang dalam kejadian komunikasi sehingga bertambah komplekslah komunikasi tersebut. Komunikasi interpersonal adalah membentuk hubungan dengan orang lain.(Muhammad, 2009: 159)

Komunikasi antar-pribadi (interpersonal communication) pada hakikatnya adalah interaksi antara seorang individu dan individu lainnya tempat lambang-lambang pesan secara efektif digunakan, terutama dalam hal komunikasi antar-manusia menggunakan bahasa. (Soyomukti, 2016 : 141) Komunikasi interpersonal adalah interaksi tatap muka antar dua atau beberapa orang, dimana pengirim dapat menyampaikan pesan secara langsung, dan penerima pesan dapat menerima dan menanggapi secara langsung pula.(Hardjana, 2003:85).

Komunikasi antarpribadi merupakan proses melalui dimana orang menciptakan dan mengelola hubungan mereka melaksanakan tanggung jawab secara timbal balik dan menciptakan makna.(Kathleen S. Verdebar et. Al, 2007) dalam Budyatna, 2011: 1415) Menurut sifatnya, komunikasi antar peribadi dapat dibedakan atas dua macam, yakni komunikasi diadik (dyadic communication) dan komunikasi kelompok kecil (small group communication).

1. Komunikasi diadik, ialah proses komunikasi yang berlangsung antara dua orang dalam situasi tatap muka.

2. Komunikasikelompok kecil, ialah proses komunikasi yang berlangsung antara tiga orang atau lebih secara tatap muka, dimana anggota-anggotanya saling berinteraksi satu sama lainnya. (Cangara, 2005: 33)

Dalam Budayatna, 2011 terdapat delapan karakteristik komunikasi anatarpribadi (komunikasi interpersonal), sebagai berikut:

1. Melibatkan paling sedikit dua orang

Apabila kita mendefinisikan komunikasi anatarpribadi dalam arti jumlah orang yang terlibat, haruslah diingat bahwa komunikasi anatarpribadi sebetulnya terjadi antara dua orang yang merupakan bagian dari kelompok yang lebih besar. Apabila dua orang dalam kelompok yang lebih besar sepakat mengenai hal tertentu atau sesuatu, maka kedua orang itu nyata-nyata terlibat dalam komunikasi anatarpribadi.

2. Adanya umpan balik balik atau feedback

Komunikasi antar pribadi melibatkan umpan balik. Umpan balik merupakan pesan yang dikirim kembali oleh penerima kepada pembicara. Dalam komunikasi antarpribadi hampir selalu melibatkan umpan balik langsung. Sering kali bersifat segera, nyata, dan berkesinambungan. Hubungan yang langsung antara sumber dan penerima merupakan bentuk yang unik bagi komunikasi antarpribadi.

\section{Tidak harus tatap muka}

Komunikasi antarpribadi tidak harus tatap muka. Bagi komunikasi antarpribadi yang sudah terbentuk, adanya saling pengertian antara dua individu, kehadiran fisik dalam komunikasi tidaklah terlalu penting. 


\section{Tidak harus bertujuan}

Komuniaksi antarpribadi tidak harus selalu disengaja atau dengan kesadaran. Misalnya, anda dapat mengetahui karena kesalahan keseleo lidah bahwa orang itu telah berbohong kepada anda. Anda mungkin mengambil keputusan untuk tidak dekat-dekat dengan seseorang karena sifatnya yang kasar atau tindak-tanduknya yang tidak anda setuju. Orang-orang itu mungkin mengkomunikasikan segala sesuatunya itu merupakan pesan-pesan bagi isyarat yang mempengaruhi anda. Dengan kata lain, terjadi penyampaian pesan-pesan dan penginterpretasian pesanpesan tersebut.

5. Menghasilkan beberapa pengaruh atau effect

Untuk dapat dianggap sebagai komunikasi antarpribadi yang benar, maka sebuah pesan harus menghasilkan atau memiliki efek atau pengaruh. Efek atau pengaruh itu tidak harus segera dan nyata, tetapi harus terjadi.

6. Tidak harus melibatkan dan menggunakan kata-kata

Bahwa kita dapat berkomunikasi tanpa kata-kata seperti pada komunikasi nonverbal.

7. Dipengaruhi oleh konteks

Konteks merupakan tempat dimana pertemuan komunikasi terjadi termasuk apa yang mendahului dan mengikuti apa yang dikatakan. Konteks mempengaruhi harapan-harapan para partisipan, makna yang diperoleh para partisipan dan perilaku mereka selanjutnya.

8. Dipengaruhi oleh kegaduhan atau noise

Kegaduhan atau noise ialah setiap rangsangan atau stimulus yang mengganggu dalam proses pembuatan pesan. Kegaduhan/kebisingan atau noise dapat bersifat eksternal, internal, atau semantik.

Berikut dijelaskan beberapa faktor yang mempengaruhi komunikasi interpersonal : (Rakhmat: 2012, 127-128)

\section{Percaya (trust)}

Di antara berbagai faktor yang mempengaruhi komunikasi interpersonal, faktor percaya adalah yang paling penting bila saya percaya kepada anda, bila perilaku anda dapat saya duga, bila saya yakin anda tidak akan mengkhianati atau merugikan saya, maka saya akan lebih banyak membuka diri saya kepada anda.

\section{Sikap suportif (suportif attitude)}

Sikap suportif adalah sikap yang mengurangi sifat difensif dalam komunikasi. Orang bersikap difensif bila ia tidak menerima, tidak jujur, dan tidak empati. Dengan sifat difensif, komunikasi anatarpribadi akan gagalkarena orang difensif akan lebih banyak melindungi diri dari ancaman yang ditanggapinya dalam situasi komunikasi ketimbang memahami pesan orang lain.

\section{Sikap terbuka (open-mindedness)}

Sikap terbuka amat besar pengaruhnya dalam menumbuhkan komunikasi interpersonal yang efektif. Keterbukaan adalah pengungkapan reaksi atau tanggapan kita terhadap situasi yang sedang dihadapi serta memberikan informasi tentang masalalu yang relevan untuk memberikan tanggapan kita di masa kini tersebut. 
Pada tahapan pelaksanaan komunikasi, agar pesan efektif diperlukan kendali komunikasi, artinya aturan-aturan yang dapat memengaruhi hubungan manusiawi (human relations) dapat diterima oleh orang lain. Kendali pesan pada komunikasi ini antara lain: (Hidayat, 2012: 115-120)

\section{Bahasa (semantic)}

Pemilihan bahasa yang benar dan tepat sangat menentukan hubungan selanjutnya.

\section{Emosi (emotion)}

Sebuah emosi adalah keadaan mental dan psikologis yang mempengaruhi sikap manusia. Seorang komunikator yang baik, disaat sedang menyampaikan pesan, dia bisa memainkan keadaan psikologis audience, kapan saatnya dia harus bersuara dengan nada tinggi, tegas, santai atau bahkan kapan saatnya membuat situasi cair dengan guyonan yang disampaikannya.

\section{Sikap (attitude)}

Sikap positif dapat menjadi fasilitas komunikasi. Melalui karakter yang baik maka pesan komunikasi dapat diterima dan dapat mempengaruhi sikap orang lain yang diajak berkomunikasi.

4. Pesan nonverbal (nonverbal message)

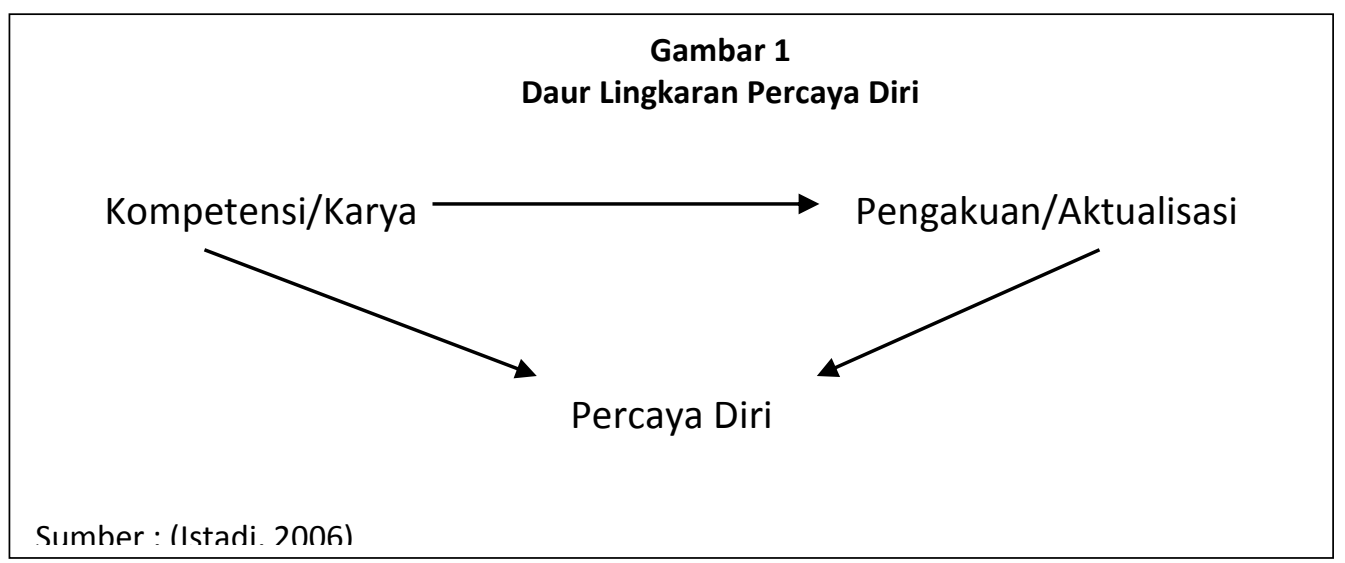

Pada saat komunikasi berlangsung, selain menggunakan pesan verbal juga nonverbal. Komunikasi nonverbal merupakan pesan yang diam tanpa adanya suara, tetapi memilki arti, seperti ekspresi wajah, gesture, kontak mata dan lainnya.

\section{Proxemiks}

Proxemiks adalah studi himpunan yang dapat diukur jarak antara orang-orang ketika mereka berinteraksi.

Percaya diri secara sederhana dapat dikatakan sebagai suatu keyakinan sesorang terhadap segala aspekkelebihan yang dimilikinya dan keyakinan tersebut membantunya merasamampu untuk bisa mencapai berbagai tujuan di dalam hidupnya. (Hakim, 2005:6)

Rasa percaya diri (adequacy) atau self esteem merupakan perasaan dimana anak mempunyai keyakinan tentang dirinya sendiri bahwa ia mempunyai konsep tentang diri sendiri. Perasaan ini juga dibangun dan dikembangkan dari interaksi dengan orang lain, yakni dari respon orang lain terhadap dirinya. (Suyadi, 2013: 154) Sementara itu 
percaya diri merupakan suatu keyakinan dalam jiwa manusia bahwa tantangan hidup apapun harus dihadapi dengan berbuat sesuatu. Percaya diri itu lahir dari kesadaran bahwa jika memutuskan untuk melakukan sesuatu, sesuatu itu pula yang harus dilakukan (Barbara, 2007: 10).

Percaya diri adalah berbuat dengan penuh keyakinan. Apa pun tantangan yang dihadapi dan dalam kondisi apapun ia akan menggapai cita-citanya. Rasa percaya diri adalah kekuatan yang mendorong seseorang untuk maju dan berkembang serta selalu memperbaiki diri. Tanpa rasa percaya diri, seseorang akan hidup di bawah bayangbayang orang lain. Ia akan selalu takut pada kegagalan dan sesuatu yang tidak diketahui. (Elfiky, 2009 dalam Kusrini, 2014: 134)

Tumbuhnya percaya diri, diawali adanya sebuah kompetensi tertentu sesuai fase perkembangan anak. Atau bisa juga berupa karya. Proses pembentukan percaya diri digambarkan dalam daur lingkaran percaya diri di bawah ini:

Dari skema siklus ini, bisa diambil kesimpulan ada dua hal utama yang bisa diupayakan keberadaannya oleh pendidik, yaitu kompetensi/ karya, dan pengakuan dari lingkungan. Cari dan dapatkan dalam bidang apa anak memiliki kompetensi dan kembangkan dengan baik, sehingga memperoleh pengakuan dari lingkungan.

Faktor-faktor yang mempengaruhi rasa percaya diri menurut Barbara (2007:4) adalah sebagai berikut:

a. Kemampuan pribadi

Rasa percaya diri hanya timbul pada saat seseorang mengerjakan sesuatu yang memang mampu dilakukan.

b. Keberhasilan seseorang

Keberhasilan seseorang ketika mendapatkan apa yang selama ini diharapkan dan cita-citakan akan menperkuat timbulnya rasa percaya diri.

c. Keinginan

Ketika seseorang menghendaki sesuatu maka orang tersebut akan belajar dari kesalahan yang telah diperbuat untuk mendapatkannya.

Anak tumbuh dan berkembang dilingkungan keluarga bersama ayah, ibu dan anggota keluarga yang lain. Rumah adalah madrasah atau sekolah pertama bagi anak. Hal ini berimplikasi bahwa orang tua adalah guru pertama bagi anak. Oleh karena itu persepsi rumah dan lembaga PAUD harus selaras, sehingga rumah menjadi sekolah awal sebelum masuk PAUD. Dalam hal ini PAUD-lah yang harus lebih aktif mensosialisasikan program-program pendidikannyauntuk menyelaraskan dengan kegiatan-kegiatan di rumah. Hal ini dimaksudkan agar kegiatan dirumah tidak bertentangan dengan kegiatan di sekolah (PAUD).

Sepanjang proses pertumbuhan dan perkembangan di lingkungan keluarga dan sosial, anak-anak memperoleh kebutuhan dasar (makanan, pakaian, dan kebersihan) dan pengalaman menerima respon dari orang dewasa (orang tua dan orang lain), serta mereka memperoleh kepuasan dari pengalaman menjajah lingkungan (dunianya) sendiri tersebut. Pengalaman-pengalaman permulaan anak merupakan landasan bagi pembentukan perasaan puas dan percaya diri karena anak mendapatkan keinginannya dan anak terpuaskan oleh karenanya. Bahkan ketika anak memperoleh respons yang layak dari orang tua (orang dewasa), serta ketika anak memperoleh kepuasan sensori yang terpuaskan maka kebutuhan anak semakin terpenuhi. 


\section{METODE PENELITIAN}

Metode penelitian yang digunakan adalah metode penelitian kuantitatif, yang berwujud angka-angka dan diperoleh dari pengukuran langsung maupun dari angkaangka yang diperoleh dengan mengubah data kualitatif menjadi data kuantitatif. (Riduwan, 2014: 32)

Metode ini menggunakan uji hipotesis, yaitu untuk mengetahui seberapa besar pengaruh variabel bebas terhadap variabel tidak bebas yang dilakukan dengan menggunakan analisis regresi linier sederhana, yang bertujuan untuk mengetahui seberapa besar pengaruh komunikasi interpersonal guru terhadap rasa percaya diri anak usia dini. Jenis penelitian ini adalah penelitian deskriptif dengan bentuk penelitian lapangan (fiels research). Populasi dalam penelitian ini adalah seluruh orang tua/wali murid dan guru RA Asiah Kota Pekanbaru yang berjumlah36 orang.

Dalam menentukan ukuran sampel penelitian peneliti menggunakan teknik pengambilan sampling jenuh, sampling jenuh ialah teknik pengambilan sampel apabila semua populasi digunakan sebagi sampel dan dikenal juga dengan istilah sensus. (Riduwan, 2014: 21). Sampel dalam penelitian ini adalah seluruh orang tua murid dan guru RA Asiah Kota Pekanbaru yang berjumlah 36 orang. Untuk pengukuran data yang digunakan adalah skala Likert untuk mengukur sikap, pendapat dan persepsi seseorang atau kelompok tentang kejadian atau gejala sosial. Dalam penelitian gejala sosial ini telah ditetapkan secara spesifik oleh peneliti, yang selanjutnya disebut sebagai variabel penelitian. (Riduwan,2014: 38).

Pada tahapan pengumpulan data, peneliti menggunakan beberapa teknik pengumpulan data kuesioner yaitu dengan membuat daftar pernyataan yang telah dipersiapkan sejumlah alternatif jawaban dan diberikan kepada responden guna memperoleh data yang berhubungan dengan pengaruh komunkasi interpersoanal guru terhadap rasa percaya diri anak usia dini. Dan dokumentasi yang diteliti berupa dukumen-dokumen yang bisa memberikan sumber informasi bagi peneliti seperti datadata murid RA AsiahKota Pekanbaru dan foto-foto kegiatan kelas. Teknik analisa data yang digunakan dalam penelitian ini adalah Analisis Regresi Linier Sederhana. Penulis menggunakan rumus Regresi Linier Sederhana dan diproses menggunakan program SPSS versi 23 .

\section{PEMBAHASAN}

Uji validitas digunakan untuk mengetahui kelayakan butir-butir dalam suatu daftar (konstruk) pernyataan dalam mendefinisikan suatu variabel. Validitas suatu pernyataan dalam angket dapat dlihat pada output SPSS pada tabel dengan nama itemtotal statistik. Suatu pernyataan dikatakan valid jika nilai r-hitung (nilai Pearson correlation) lebih besar dari nilai r-tabel. Namun sebaliknya jika nilai r-hitung lebih kecil dari nilai r-tabel, maka item tersebut dikatakan tidak valid, dengan:

$\mathrm{r}$ tabel $=\mathrm{n}-2$

$$
=36-2
$$

$=34$, dengan nilai $\mathrm{r}$ tabel pada tabel $\mathrm{r}$ product moment 0,339

Berikut hasil SPSS versi 23 dalam perhitungan hasil pernyataan angket: 
Tabel 1

Hasil Uji Validasi Item

\begin{tabular}{|c|c|c|c|}
\hline $\begin{array}{c}\text { Nomor } \\
\text { Pernyataan }\end{array}$ & $\begin{array}{c}\text { Komunikasi } \\
\text { Interpersonal } \\
\text { Guru } \\
\text { rhitung }\end{array}$ & $\begin{array}{c}\text { Rasa Percaya } \\
\text { Diri Anak } \\
\text { Usia Dini } \\
\text { rhitung }\end{array}$ & $\begin{array}{c}\text { Keterangan } \\
\text { r-hitung } \geq \\
0,339\end{array}$ \\
\hline 1 & $\frac{\text { r hitung }}{0.420}$ & r hitung & Valid \\
\hline 2 & 0,686 & - & Valid \\
\hline 3 & 0,460 & - & Valid \\
\hline 4 & 0,535 & - & Valid \\
\hline 5 & 0,632 & - & Valid \\
\hline 6 & 0,513 & - & Valid \\
\hline 7 & 0,488 & - & Valid \\
\hline 8 & 0,700 & - & Valid \\
\hline 9 & 0,624 & - & Valid \\
\hline 10 & 0,472 & - & Valid \\
\hline 11 & 0,689 & - & Valid \\
\hline 12 & 0,796 & - & Valid \\
\hline 13 & 0,345 & - & Valid \\
\hline 14 & 0,429 & - & Valid \\
\hline 15 & 0,518 & - & Valid \\
\hline 16 & 0,529 & - & Valid \\
\hline 17 & 0,700 & - & Valid \\
\hline 18 & 0,610 & - & Valid \\
\hline 19 & - & 0,462 & Valid \\
\hline 20 & - & 0,591 & Valid \\
\hline 21 & - & 0,754 & Valid \\
\hline 22 & - & 0,773 & Valid \\
\hline 23 & - & 0,620 & Valid \\
\hline 24 & - & 0,624 & Valid \\
\hline 25 & - & 0,703 & Valid \\
\hline 26 & - & 0,572 & Valid \\
\hline 27 & - & 0,528 & Valid \\
\hline 28 & - & 0,653 & Valid \\
\hline 29 & - & 0,664 & Valid \\
\hline 30 & - & 0,395 & Valid \\
\hline
\end{tabular}

Sumber: Data Olahan Angket 2017

Berdasarkan tabel di atas, seluruh item pernyataan untuk variabel x (pengaruh komunikasi interpersonal guru) daan variabel y (meningkatkan rasa percaya diri anak), nilai koefisiennya (r-hitung) lebih besar dibandingkan r-tabel, sehingga semua item dinyatakan valid.

Uji regresi linier sederhana untuk mengetahui pengaruh komunikasi interpersonal guru dalam meningkatkan rasa percaya diri anak usia dini Raudatul Athfal Asiah Kota Pekanbaru, peneliti menggunakan rumus regresi linier sederhana dengan bantuan program SPSS versi 23, adapun rumus yang digunakan adalah:

$\mathrm{Y}=\mathrm{a}+\mathrm{bX}$

Keterangan:

$\mathrm{Y} \quad=$ rasa percaya diri anak

$\mathrm{X} \quad=$ komunikasi interpersonal guru

$\mathrm{a} \quad=$ konstanta (harga Y bila $\mathrm{X}=0$ )

$\mathrm{b} \quad=$ =koefisien regresi, yang menunjukkan angka peningkatan atau penurunan variabel bebas $(\mathrm{X})$ yang didasarkan pada hubungan variabel terikat $(Y)$ 
Tabel 2

Hasil Analisis Regresi Sederhana

\begin{tabular}{lll}
\hline Variabel & Koefisien Regresi & t-hitung \\
\hline Konstanta & $-1,579$ & $-0,302$ \\
\hline Pengaruh Komunikasi Interpersonal & 0,682 & 10,284 \\
& & \\
\hline $\mathrm{R}=0,870$ & & \\
$\mathrm{R}$ Square $=0,757$ & & \\
Adjust $\mathrm{R}=0,750$ & & \\
& &
\end{tabular}

Sumber: Data Olahan Angket 2017

Berdasarkan tabel di atas, regresi linier sederhana didapat bilangan konstanta (a) sebesar 1,579 dan koefisien variabel pengaruh komunikasi interpersonal guru sebesar 0,682. Dengan demikian dapat ditentukan persamaan regresinya sebagai berikut:

$\mathrm{Y}=\mathrm{a}+\mathrm{bX}$

$\mathrm{Y}=-1,579+0,682$

Keterangan:

$\mathrm{Y}=$ Rasa percaya diri anak usia dini

$\mathrm{a}=$ Konstanta

$\mathrm{b}=$ Koefisien regresi variabel dependen

$\mathrm{X}=$ Pengaruh komunikasi interpersonal guru

Sehingga pengaruh komunikasi interpersonal guru $=-1,579+0,682$ rasa percaya diri anak usia dini, dijabarkan dalam persamaan regresi di atas sebagai berikut :

1. Nilai konstanta (a) sebesar $-1,579$, artinya apabila rasa percaya diri anak usia dini diasumsikan nol (0), maka pengaruh komunikasi interpersonal guru bernilai -1,579 satuan.

2. Nilai koefisien regresi rasa percaya diri anak sebesar 0,682. Artinya setiap adanya rasa percaya diri pada anak usia dini sebesar 1 satuan, maka akan meningkatkan pengaruh komunikasi interpersonal sebesar 0,682.

3. Tingkat korelasi yaitu sebesar 0,870 . Hal ini menunjukkan bahwa tingkat hubungan antara variabel independent terhadap variabel dependent sangat kuat.

Tabel 2

Pedoman Nilai Koefisien Korelasi $\left(\mathrm{R}^{2}\right)$

\begin{tabular}{ll}
\hline Interval Koefien & Tingkat Hubungan \\
\hline $0,00-0,199$ & Sangat Rendah \\
$0,20-0,399$ & Rendah \\
$0,40-0,599$ & Cukup \\
$0,60-0,799$ & Kuat \\
$\mathbf{0 , 8 0}-\mathbf{1 , 0 0 0}$ & Sangat Kuat \\
\hline
\end{tabular}

Sumber: Riduwan,2014: 228 
Pengujian Hipotesis dan Koefisien

Uji Signifikansi

Hipotesis penelitian:

$\mathrm{H}_{0} \quad$ :Tidak terdapat pengaruh antara komunikasi interpersonal guru terhadap peningkatan rasa percaya diri anak usia dini.

$\mathrm{H}_{\mathrm{a}} \quad$ :Terdapat pengaruh antara komunikasi interpersonal guru terhadap peningkatan rasa percaya diri anak usia dini.

Dengan cronbach alpha $\alpha$ 0,05 dan kriteria sebagai berikut:

Signifikansi $>\alpha=(0,05)$, maka $\mathrm{H}_{0}$ diterima dan $\mathrm{H}_{\mathrm{a}}$ ditolak

Signifikansi $<\alpha=(0,05)$, maka $\mathrm{H}_{0}$ ditolak dan $\mathrm{H}_{\mathrm{a}}$ diterima

Berdasarkan output data dengan bantuan SPSS versi 23 diperoleh nilai signifikansi sebesar 0.000 , kriteria pengujian: 0,000 $<\alpha=0,05$, maka $\mathrm{H}_{0}$ ditolak dan $\mathrm{H}_{\mathrm{a}}$ diterima.

Jika t hitung < $\mathrm{t}$ tabel , maka $\mathrm{H}_{0}$ diterima dan $\mathrm{H}_{\mathrm{a}}$ ditolak

Jika t hitung $>\mathrm{t}$ tabel, maka $\mathrm{H}_{0}$ ditolak dan $\mathrm{H}_{\mathrm{a}}$ diterima

$\mathrm{t}$ tabel $=\mathrm{n}-\mathrm{k}-1:$ alpha $/ 2$

$=36-1-1: 0,05 / 2$

$=34: 0,025$

$=1,480$

thitung $(10,284)>t$ tabel $(1,480)$, maka $\mathrm{H}_{0}$ ditolak dan $\mathrm{H}_{\mathrm{a}}$ diterima

Berdasarkan hasil pembahasan di atas, dapat dibuktikan bahwa hipotesis alternatif dapat diterima karena komunikasi interpersonal guru berpengaruh signifikan dalam meningkatkan rasa percaya diri anak usia dini. Hal ini terbukti dengan diketahui Sig. $(0,000)>0,05$ dan nilai t hitung $(0,284)>t$ tabel $(1,480)$. Artinya ada pengaruh komunikasi interpersonal guru dalam meningkatkan rasa percaya diri anak usia dini khususnya murid Raudatul Athfal Asiah Kota Pekanbaru.

\section{KESIMPULAN}

Berdasarkan penelitian yang telah dilakukan, maka penulis dapat menarik kesimpulan bahwa terdapat pengaruh komunikasi interpersonal guru berpengaruh dalam meningkatkan rasa percaya diri anak usia dini Raudatul Athfal Asiah Kota Pekanbaru. Hal ini terbukti dengan diketahui t hitung $(10,284)>t$ tabel $(1,480)$ dan tingkat signifikan $(0,000)<0,05$. Maka $\mathrm{H}_{0}$ ditolak dan $\mathrm{H}_{a}$ diterima, artinya komunikasi interpersonal guru memberikan pengaruh yang signifikan dalam meningkatkan rasa percaya diri anak usia dini yaitu murid Raudatul Athfal Asiah Kota Pekanbaru.

\section{DAFTAR PUSTAKA}

Barbara, Angelis. (2007), PercayaDiri. Jakarta.PT GramediaPustakaUtama.

Budyatna, Muhammad \&Ganiem Leila Mona.(2011), TeoriKomunikasiAntarpribadi. Jakarta: Kencana.

Cangara, H. Hafied. (2005),Pengantar Ilmu Komunikasi.Jakarta.PT Raja Grafindo Persada. 
Volume 6 Nomor 2

ISSN: 2303-0194

E-ISNN: 2615-1308

Effendi, Onong Uchjana. (2008), Dinamika Komunikasi, Bandung. PT. Remaja Rosdakarya

Hakim, Thursan. (2005),Mengatasi Rasa Tidak Percaya Diri. Jakarta : Puspa Swara.

Hardjana. Agus M. (2003),Komunikasi intrapersonal \& Komunikasi Interpersonal. Yogyakarta: Penerbit Kanisius.

Hidayat, Dasrun. (2012), Komunikasi Antar Pribadi dan Medianya. Yogyakarta. Graha Ilmu.

Istadi, Irawati. (2006), Melipat Gandakan Kecerdasan Emosi Anak. Bekasi. Pustaka Inti.

Muhammad, Arni. (2009),Komunikasi Organisasi. Jakarta. Bumi Aksara.

Mulyana, Deddy. (2011), IlmuKomunikasiSuatuPengantar, Bandung: PT. RemajaRosdakarya

Mulyasa. (2012). Manajemen PAUD. Bandung. Remaja Rosdakarya

Rakhmat, Jalaluddin. (2012), Psikologi Komunikasi, Bandung. PT Remaja Rosdakarya.

Riduwan, (20014). Dasar-dasar Statistika. Bandung. Alfabeta.

Soyomukti, Nuraini. (2016), Pengantar Ilmu Komunikasi. Jogjakarta: Ar-Ruzz Media.

Suyadi, dan Ulfah Maulidya. (2013), Konsep Dasar Paud, Bandung: PT. Remaja Rosdakarya

Jurnal

Kusrini, Woro., \& Prihartanti, Nanik. (2014), "Hubungan Dukungan Sosial Dan Kepercayaan Diri Dengan Prestasi Bahasa Inggris Siswa Kelas Viii Smp Negeri 6 Boyolali" Jurnal Penelitian Humaniora, Vol. 15, 